\title{
Modelling inactivation kinetics of waterborne pathogens in municipal wastewater using ozone
}

\author{
Achisa C Mecha ${ }^{1^{\dagger}}$, Maurice S Onyango ${ }^{2}$, Aoyi Ochieng ${ }^{3}$, Maggy NB Momba ${ }^{4}$ \\ ${ }^{1}$ Department of Chemical and Process Engineering1, Moi University, Kenya \\ ${ }^{2}$ Department of Chemical, Metallurgical and Materials Engineering, Tshwane University of Technology, Pretoria, South Africa \\ ${ }^{3}$ Botswana International University of Science and Technology, Botswana \\ ${ }^{4}$ Department of Environmental, Water and Earth Sciences, Tshwane University of Technology, South Africa
}

\begin{abstract}
Microbial water pollution is a key concern leading to waterborne diseases. This study evaluated the disinfection of wastewater using ozonation. The following aspects were investigated: inactivation efficiency against Escherichia coli, Salmonella species, Shigella species, and Vibrio cholerae; modelling of inactivation kinetics using disinfection models; and evaluation of microbial regrowth studies. $99 \%$ bacterial inactivation was obtained within $15 \mathrm{~min}$, irrespective of the water matrix, showing the strong oxidizing potential of ozone. The disinfection data were fitted into the log-linear and Weibull models. The survival curves were non-linear and fitted the Weibull model (fractional bias and normalized mean square error equal to 0.0$)$, especially at high bacterial concentrations $\left(10^{6} \mathrm{CFU} / \mathrm{mL}\right)$. The inactivation occurred in two stages: an initial rapid stage (15 min) and a final slow stage exhibiting a tailing mechanism $(15-45 \mathrm{~min})$ probably as a result of the self-defence mechanisms adopted by the bacteria to limit oxidative stress. Considering the pattern of survival curves, no significant differences $(p>0.05)$ were observed among the four tested bacterial species; thus showing that ozone was effective against all the bacteria tested. There was minimal bacterial regrowth in the treated samples 24 $\mathrm{h}$ after ozone disinfection with reactivation values of $0-5 \%$ obtained.
\end{abstract}

Keywords: Disinfection, Modelling, Municipal wastewater, Ozone, Regrowth

\section{Introduction}

Disinfection of water and wastewater is paramount to ensure public health and environmental protection. Chlorination is the most commonly used disinfection method because of its advantages such as relatively low cost, ease of application and residual bactericidal effect [1]. However, the application of chlorine suffers drawbacks due to the formation of disinfection by-products (DBPs) which are carcinogenic to humans. There is therefore a great need to explore the use of alternative disinfectants such as ozone which is a strong germicide against bacteria, viruses and protozoa because of its high oxidizing capacity (standard oxidation potential 2.07 V) $[1,2]$. Its oxidizing power is superior to that of chlorine, chlorine dioxide, and chloramines for the inactivation of different waterborne pathogens and therefore requires shorter contact times (4 to 5 times less than chlorine) for antimicrobial action $[3,4]$. In wastewater treatment, apart from disinfection, ozone also simultaneously oxi- dizes organic compounds, forms limited DBPs, and can remove undesirable odours and colour, thus improving the overall wastewater quality [1]. Similarly, ozonation reduces the overall toxicity of wastewater $[5,6]$. However, consideration should be taken during wastewater treatment using ozone since the competitive reactions of ozone with the water matrix contribute to the ozone demand [7].

Generally, ozone disinfection occurs by disrupting the cell membrane and protoplasm of microorganisms, which impedes cell reactivation in bacteria, coliform, viruses, and protozoa [8]. Moreover, ozone can easily diffuse through the cell membrane into the cytoplasm of cells and cause direct oxidation of cellular components [9]. Disinfection studies mainly use E. coli as a model indicator microorganism and its presence indicates possible contamination with waterborne pathogens [10, 11]; based on this, most national wastewater treatment standards focus only on coliform bacteria such as E. coli [12]. However, apart from E. coli, information regarding the behaviour of other bacteria during disinfection is very lim-
This is an Open Access article distributed under the terms of the Creative Commons Attribution Non-Commercial License (http://creativecommons.org/licenses/by-nc/3.0/) which permits unrestricted non-commercial use, distribution, and reproduction in any medium, provided the original work is properly cited.

Copyright (C) 2020 Korean Society of Environmental Engineers
Received October 21, 2019 Accepted December 05, 2019

${ }^{\dagger}$ Corresponding author

Email: achemeng08@gmail.com

Tel: +254726371174 Fax: +254 (53) 43074

ORCID: 0000-0002-6252-8340 
ited, even though the bacterial content of wastewater comprises different species which differ markedly in their sensitivity to various disinfecting agents [13]. Furthermore, the absence of coliforms and E. coli in treated water should not be relied upon as adequate assurance that the pathogens will also be absent since most of the indicator bacteria are non-pathogenic [14]. This makes it necessary to investigate the ozone disinfection of different water pathogens in addition to E. coli.

Previous studies on ozone disinfection efficacy have been done using pure cultures in synthetic water [15], surface water [11], well water [16]. There is a need to investigate ozone disinfection of municipal wastewater intended for reuse. Therefore, ozone detoxification and disinfection of municipal wastewater is important to enable water-scarce countries explore opportunities for wastewater reuse. Some disinfectants temporarily inactivate bacteria and thereafter the bacteria may become active and still pose risk to water consumers. This is more prevalent in wastewater since it contains biological nutrients that can provide nutrition for the bacteria. To determine whether complete disinfection has occurred, bacterial re-growth post-disinfection studies should be conducted. This study goes beyond just assessing the disinfection performance of ozone against the indicator bacteria, E. coli; it assesses the performance against three other bacteria. It also evaluates the kinetic modelling of disinfection data using non-linear models; most studies assume first order kinetics only. The study also evaluates bacterial reactivation and regrowth after disinfection and suggests ways to overcome this.

The degradation of organic micro pollutants using ozone was investigated in a previous study [17], and the present study thus focuses on the disinfection aspect. The objectives of this study were therefore: (1) to investigate the efficacy of ozone for inactivating E. coli, Salmonella species, Shigella species, and Vibrio cholerae in different water matrices; (2) to describe the inactivation kinetics using log-linear and Weibull disinfection models based on the Geeraerd and Van Impe Inactivation Model Fitting Tool (GInaFiT); and (3) to perform microbial re-growth studies to determine the effectiveness of ozone disinfection.

\section{Material and Methods}

\subsection{Reagents}

Potassium iodide (KI), sodium thiosulphate, hydrochloric acid, starch, trypticase soy agar (TSA), xylose lysine deoxycholate (XLD) agar, and thiosulphate-citrate-bile salts-sucrose (TCBS) agar were obtained from Merck (Pty) Ltd (South Africa). All chemicals used were of analytical grade and were therefore used without any modification. All solutions were prepared using Milli-Q water. Ozone was produced using an air-fed ozone generator (Wassertec, Light Blue ozone generator).

\subsection{Water Samples}

Synthetic water (SW) and secondary wastewater (SWW) effluent were used in this study. All glass apparatus used in the experiments were autoclaved at $121^{\circ} \mathrm{C}$ for $30 \mathrm{~min}$ and aseptic handling of materials and laboratory facilities was observed in order to maintain sterility.

\subsubsection{Preparation of synthetic water}

Fresh bacterial cultures were maintained in nutrient agar (Biolab, South Africa) plates and incubated at $37^{\circ} \mathrm{C}$ for $24 \mathrm{~h}$. One loop full of this bacterial culture was inoculated into $100 \mathrm{~mL}$ of sterile nutrient broth (Biolab, South Africa) and incubated for $24 \mathrm{~h}$ at $37^{\circ} \mathrm{C}$ in a shaking incubator (Scientific, Lasec SA (Pty) Ltd) at a speed of $100 \mathrm{rpm}$. Thereafter, $1 \mathrm{~mL}$ each of the four cultures was serially diluted in $9 \mathrm{~mL}$ saline water $(0.9 \% \mathrm{w} / \mathrm{v} \mathrm{NaCl})$ and pour-plated onto the media as follows: TSA for E. coli, XLD agar for Salmonella species and Shigella species, and TCBS agar for $V$. cholerae. The plates were incubated at $37^{\circ} \mathrm{C}$ for $24 \mathrm{~h}$ and the resulting colonies were counted to obtain the initial bacterial concentrations $(\mathrm{CFU} / \mathrm{mL})$. Aliquots of the bacterial cultures corresponding to $10^{6} \mathrm{CFU} / \mathrm{mL}$ were inoculated into $1 \mathrm{~L}$ of sterile saline deionised water $(0.9 \% \mathrm{w} / \mathrm{v} \mathrm{NaCl})$ and shaken vigorously to ensure proper mixing and then pumped in the reactor. Three trials were done to evaluate the performance of the ozonation systems in treating the synthetic water. The concentrations of the target bacteria were quantified before and after treatment using the pour-plate method [18].

\subsubsection{Characterization of municipal wastewater}

The SWW effluent was obtained from Daspoort wastewater treatment plant in Pretoria, South Africa. The wastewater samples were collected in sterile $5 \mathrm{~L}$ plastic buckets. The wastewater samples were also collected in sterile $1 \mathrm{~L}$ glass bottles to detect and enumerate the initial concentration of bacteria before treatment. The samples were transported to the laboratory and assayed for microbiological and physicochemical parameters using standard methods [18] within $4 \mathrm{~h}$ to determine the wastewater quality prior to treatment. The composition of SWW is shown in Table 1. Following the pre-enrichment step, the four bacteria were quantified using membrane filtration [18]; and also after treatment. Three trials were also done and average values calculated.

\subsection{Ozonation Equipment Set-Up and Process Description}

The experimental system employed is similar to the one used in a previous study [17]. Briefly, the ozonation system consisted of a cylindrical reactor $(700 \mathrm{~mL})$ with continuous ozone supply from an ozone generator (Wassertec, Light Blue ozone generator). Ozone was generated by corona-discharge method using dry compressed air and bubbled into the bottom of the reactor by means of a pipe diffuser. The mixture of ozone and the bacterial suspension was gently stirred using a magnetic stirring bar in order to ensure a homogeneous distribution in the reactor (Fig. S1). Samples were periodically collected in sterile bottles via a Teflon tap placed at the bottom of the reactor. The samples were analysed in triplicate using the pour-plate method to quantify the microbial inactivation. The plates were incubated at $37^{\circ} \mathrm{C}$ for $24 \mathrm{~h}$ after which colony counts were determined. To investigate the ability of bacteria to undergo repair after ozone disinfection, bacterial re-growth studies were conducted for samples in which complete microbial inactivation was achieved. These samples were stored at room temperature in sterile vials for $24 \mathrm{~h}$; thereafter, the pour-plate technique was used to establish whether any bacterial re-growth had taken place. Similarly, control experiments were conducted using air instead of ozone. 


\subsection{Analytical Methods}

The chemical oxygen demand (COD) was determined using standard method 5220 [18]. Turbidity was measured using a $2100 \mathrm{~N}$ Laboratory Turbidimeter (Hach, USA). The $\mathrm{pH}$ was measured using an HQ30d portable pH meter (Hach, USA). The mass of ozone collected in the KI trap was determined using the standard method 2350E [18]. Dissolved oxygen (DO) was measured using an LDO meter (Hach, USA).

\subsection{Disinfection Kinetics and Modelling of Survival Curves}

The disinfection efficiency $(R)$ was calculated as:

$$
R=\left(\frac{N_{o}-N}{N_{o}}\right) \times 100
$$

where $R$ is the disinfection efficiency, $N_{\mathrm{o}}$ and $N$ are the number of viable microorganisms (CFU/mL) at the start of the process and at an ozonation time $t$, respectively.

Disinfection efficacy was also expressed in terms of log reduction values (LRVs):

$$
L R V=-\log \left(\frac{N}{N_{o}}\right)
$$

The bacterial survival was predicted using two models, namely the Chick-Watson model and the Weibull model for comparison. The Chick-Watson model is expressed by the following equation $[19,20]$ :

$$
\log \left(\frac{N}{N_{o}}\right)=-k[c]^{n} t
$$

where $k$ is the disinfection kinetic constant, $c$ is the concentration of the disinfecting agent at time $t$, and $\mathrm{n}$ the reaction order.

The concentration of the disinfecting agent (ozone) was kept constant and consequently, Eq. (4) can be written as follows:

$$
\log \left(\frac{N}{N_{o}}\right)=-k^{\prime} t
$$

where $k^{\prime}$ is the microbial inactivation rate constant $\left(\mathrm{min}^{-1}\right)$. This log-linear model was used to fit the ozone disinfection data.

The Weibull model for bacterial inactivation is expressed as [21]:

$$
\log N=\log N_{o}-\left(\frac{t}{\delta}\right)^{\beta}
$$

where $\delta$ ( $\mathrm{min}$ ) is time for the first decimal reduction and $\beta$ is a parameter related to the scale and shape of the inactivation curve and the other parameters have the same meaning as stated before.

The log-linear and Weibull models were fitted to the disinfection data using the GInaFiT tool [22] and evaluated for goodness of fit.

\subsection{Evaluation of Bacterial Reactivation}

To evaluate the reactivation of bacterial cells after $24 \mathrm{~h}$ retention in the dark, the percentage degree $(D)$ of reactivation or decay was quantified using a method in the literature [14]:

$$
D=\left(\frac{N_{r}-N}{N_{o}-N}\right) \times 100
$$

where $N_{r}(\mathrm{CFU} / \mathrm{mL})$ is the concentration of the bacteria in treated wastewater after $24 \mathrm{~h}$ retention in the dark.

Eq. (6) gives the percentage of reactivated bacterial cells after ozone disinfection.

\subsection{Statistical Analysis and Model Performance Evaluation}

The root mean square error (RMSE), which measures the average deviation between the observed and the fitted values, was used to evaluate the performance of the models [23]:

$$
R M S E=\sqrt{\sum_{1}^{n_{t}} \frac{\left(y_{\text {expi }}-y_{p r e}\right)^{2}}{n_{t}-n_{p}}}
$$

where $y_{\text {expi }}$ values represent the experimental observations; $y_{\text {pre }}$ values represent model predictions; $n_{t}$ values represent the number of data points; and $n_{p}$ values represent the number of estimated model parameters.

The model with the smaller RSME value was considered the best fit for the respective inactivation curve. Regression analysis of the microbial inactivation data was performed and the coefficient of determination $\left(R^{2}\right)$ was calculated and used to compare the fitting of models to experimental data. The differences of inactivation among the pathogens investigated were analysed using a paired $t$-test at $95 \%$ confidence level. To further evaluate the model predictions with observations, the fractional bias (FB) and the normalized mean square error (NMSE) were also determined.

$$
\begin{gathered}
F B=\frac{\left(\overline{C_{o}}-\overline{C_{p}}\right)}{0.5\left(\overline{C_{o}}+\overline{C_{p}}\right)} \\
N M S E=\frac{\left(\overline{\overline{C_{o}}-\overline{\overline{C_{p}}}}\right)^{2}}{\overline{{C_{o}}_{C_{p}}}}
\end{gathered}
$$

where $C_{p}$ is model predictions and $C_{o}$ is observations. For a perfect model, the FB and NMSE $=0.0$ [24].

\section{Results and Discussion}

\subsection{Operating Conditions}

Ozone concentration of $20.83 \mathrm{mg}-\mathrm{min} / \mathrm{L}$ was used based on a previous study which showed that this concentration was optimal for high contaminant abatement as well as high ozone utilisation efficiency of 95\% [17]. The $\mathrm{pH}$ of the wastewater ( $\mathrm{pH}$ 6.8) was not adjusted prior to ozone disinfection, because the majority of human pathogens prefer a neutral $\mathrm{pH}$. It is because of this that most of the disinfection studies reported have been performed in the $\mathrm{pH}$ range of 5-8 [25, 26]. A control experiment was conducted (using air instead of ozone) and no disinfection was observed, indicating that the performance reported in this study is attributed to the action of ozone. 


\subsection{Effect of Water Matrix on Ozone Disinfection}

\subsubsection{Treatment of synthetic water (SW) spiked with microbes $\left(10^{3} \mathrm{CFU} / \mathrm{mL}\right)$}

The efficacy of ozone disinfection can be demonstrated readily when the target microorganisms are spiked in pure water (with low ozone demand) than in complex matrices such as wastewater. Disinfection of synthetic water spiked with $10^{3} \mathrm{CFU} / \mathrm{mL}$ of microbes was conducted and the results are presented in Fig. 1. The disinfection efficacy increased with contact time; within the first 2 min inactivation efficiencies of 75 to $80 \%$ were observed. The highest inactivation efficiency $(R=99.5 \%)$ was obtained for $V$. cholerae, and near complete deactivation occurred within 5 min, while the other pathogens were completely deactivated within 10 min (Fig. 1 and Table S1). At a contact time of $10 \mathrm{~min}$, the disinfection efficiency was observed to be higher than 99.9\%, corresponding to a 3-log reduction for all the pathogens (Table S1). These results corroborate the findings of $\mathrm{Xu}$ and co-workers [27] and Michael-Kordatou and colleagues [28] who reported 3-log reduction of E.coli within $15 \mathrm{~min}$. For all the four bacterial species tested, ozone was effective and no bacteria were detected in the treated water after $10 \mathrm{~min}$. This could mean that the microbes were well exposed to ozone leading to the oxidation and lysis of the bacteria as the synthetic water did not contain any interfering ions and organic compounds. The solution $\mathrm{pH}$ of the bacterial mixture dropped from $\mathrm{pH} 6.8$ to $\mathrm{pH} 6.0$ within $10 \mathrm{~min}$ of ozonation. This could be attributed to the oxidation and lysis of the bacteria thereby leading to the release of intracellular components that are acidic [29]. Furthermore, the dissolved oxygen concentration also increased from 5.5 to $6.9 \mathrm{mg} / \mathrm{L}$ within $5 \mathrm{~min}$ because of ozone decomposition to oxygen and then levelled off for the rest of the reaction time probably due to attainment of the saturation level [30].

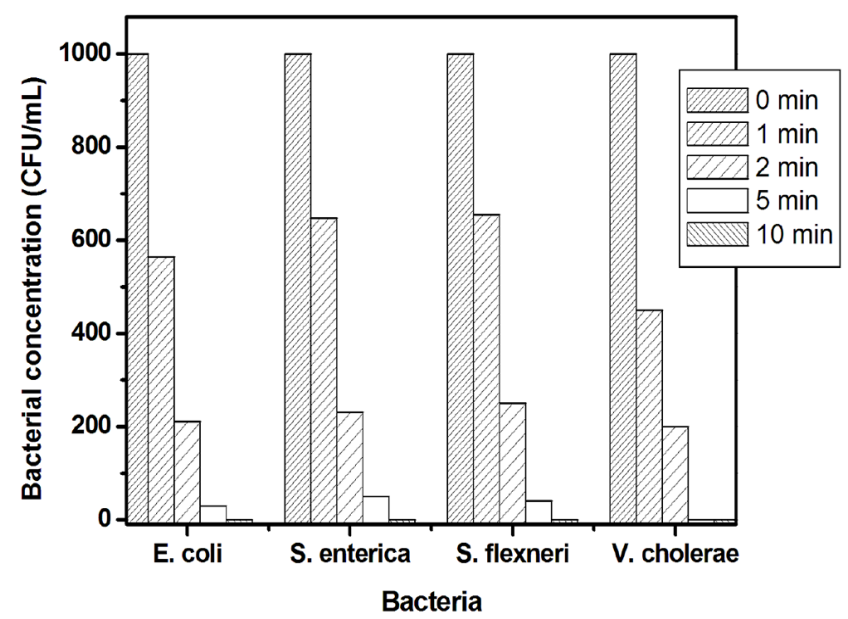

Fig. 1. Disinfection of synthetic water spiked with microbes $\left(10^{3} \mathrm{CFU} / \mathrm{mL}\right)$.

\subsubsection{Treatment of SWW}

The composition of the SWW was presented in Table 1. The SWW contained significant concentrations of the target waterborne pathogens as well as an organic load represented as COD. Disinfection of SWW showed that although there was a drastic reduction in the bacterial concentrations during the initial stage ( $5 \mathrm{~min}$ ), complete removal was only achieved in 45 min especially for E.coli which had the highest concentration in SWW. Furthermore, complete inactivation of $V$. cholerae and Shigella species was achieved in approximately 10 and $15 \mathrm{~min}$, respectively. This could be attributed to their relatively low concentrations in the wastewater. Moreover, 1 to $2.3 \log$ reductions were attained (Table S2). Based on the fact that the bacterial concentration in SWW was one order of magnitude lower than that spiked in the SW (Fig. 2), the presence of other constituents such as organic matter (COD) and indigenous non-target microorganisms in the SWW could have increased the ozone demand and hence reduced the effectiveness of ozone disinfection. This consequently increased the contact time required for complete disinfection [31]. This demonstrates the need to conduct disinfection studies using real wastewater samples rather than synthetic water so as to obtain realistic results.

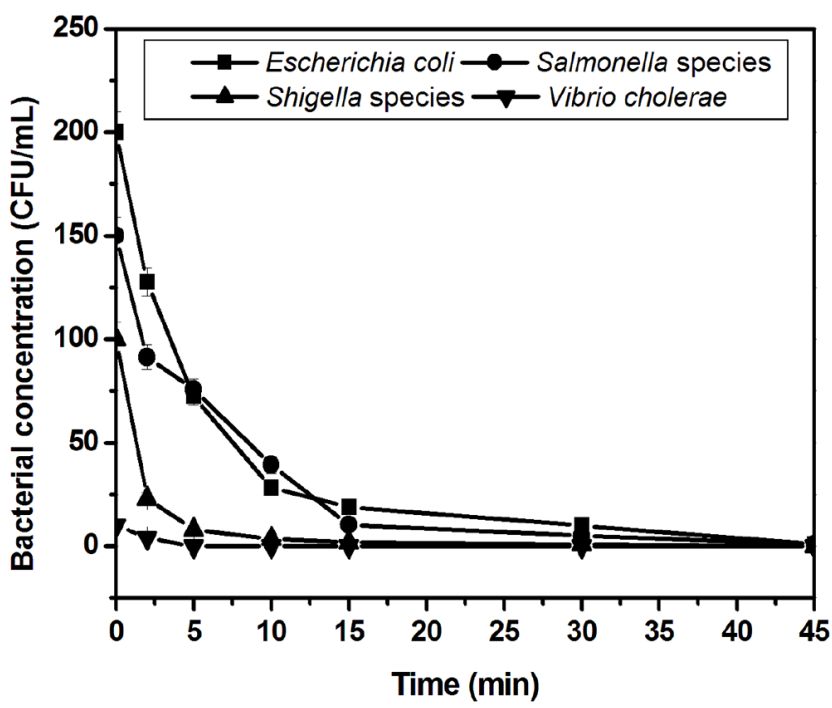

Fig. 2. Disinfection of secondary wastewater.

\subsubsection{Treatment of SWW spiked with $106 \mathrm{CFU} / \mathrm{mL}$ bacteria}

To evaluate the performance of ozone disinfection at high microbial concentrations in wastewater, the SWW was spiked with the target microbes since their concentrations in the environmental samples were low. Moreover, to eliminate the effect of other non-target microorganisms present in the wastewater, the wastewater sample was autoclaved $\left(121^{\circ} \mathrm{C}, 30 \mathrm{~min}\right)$ and cooled to room temperature and then spiked with $10^{6} \mathrm{CFU} / \mathrm{mL}$ of each of the target pathogens.

Table 1. Composition of the Secondary Effluent

\begin{tabular}{cccccccc}
\hline Parameter & $\mathbf{p H}$ & $\boldsymbol{E}$. $\boldsymbol{c o l i}$ & Salmonella species & Shigella species & V. cholerae & COD & T \\
\hline Unit & - & $\mathrm{CFU} / \mathrm{mL}$ & $\mathrm{CFU} / \mathrm{mL}$ & $\mathrm{CFU} / \mathrm{mL}$ & $\mathrm{CFU} / \mathrm{mL}$ & $\mathrm{mg} / \mathrm{L}$ & $\mathrm{NTU}$ \\
Value & 6.8 & 200 & 159 & 95 & 10 & 32 & $<1^{\mathrm{a}}$ \\
\hline
\end{tabular}

COD- chemical oxygen demand; $\mathrm{T}$ - turbidity; ${ }^{\mathrm{a}}$ decanted water 
Table 2. Disinfection efficiencies and LRVs for treatment of $10^{6} \mathrm{CFU} / \mathrm{mL}$ spiked SWW

\begin{tabular}{|c|c|c|c|c|c|c|c|c|}
\hline & \multicolumn{4}{|c|}{$\mathbf{R}$} & \multicolumn{4}{|c|}{ LRV } \\
\hline & $5 \mathrm{~min}$ & $15 \mathrm{~min}$ & $30 \mathrm{~min}$ & $45 \mathrm{~min}$ & $5 \mathrm{~min}$ & $15 \mathrm{~min}$ & $30 \mathrm{~min}$ & $45 \mathrm{~min}$ \\
\hline E. coli & 96.5 & 99.9 & 99.995 & 99.9999 & 1.46 & 3 & 4.3 & 6 \\
\hline S. enterica & 93.8 & 99.925 & 99.9955 & 99.9999 & 1.21 & 3.12 & 4.35 & 6 \\
\hline S. flexneri & 94 & 99.935 & 99.9965 & 99.9999 & 1.22 & 3.19 & 4.46 & 6 \\
\hline V. cholerae & 95 & 99.945 & 99.997 & 99.9999 & 1.3 & 3.26 & 4.52 & 6 \\
\hline
\end{tabular}

Prior to use, the sterility of the wastewater was aseptically checked by pour plate methods. The disinfection results are shown in Table 2. Complete disinfection of all the pathogens was achieved within $45 \mathrm{~min}$; this is approximately the contact time that was required to disinfect SWW (Table 2). This finding supports the idea that municipal wastewater contains a complex indigenous microbial community whose composition and physiological state can influence the efficiency of inactivation of target bacteria [14]. Therefore, by eliminating this effect, the study was able to show the effectiveness of ozone in treating high concentrations of the target bacteria in SWW.

\subsection{Modelling of Microbial Inactivation Kinetics}

\subsubsection{Modelling ozone treatment of SWW}

The disinfection data presented in Table S2 were fitted to the Weibull model as shown in Fig. 3(a)-(d) and to the log-linear model as shown in Fig. S2(a)-(d). The Weibull model provided a better fit of the data unlike the log-linear model; hence, the first-order kinetics does not adequately describe the data. It was further observed that the survival curves for all the pathogens were concave downward $(\beta>1)$ indicating that the cells had become increasingly damaged with increasing contact time [32]. This means that the microorganisms were possibly inactivated or killed during ozone treatment. The best-fit kinetic parameters for the two disinfection models were compared and are summarised in Table S3. Similarities among the different microorganisms tested were observed with respect to population reduction and the overall pattern of survival
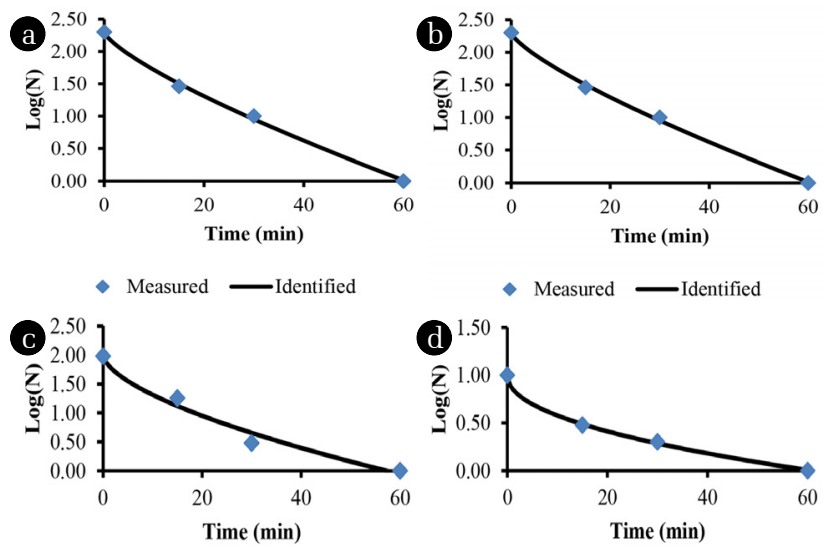

- Measured Identified

- Measured -Identified

Fig. 3. Experimental survival curve values (measured) and model fitted values (identified) derived from Weibull model for bacterial pathogens in SWW. curves. The Weibull model was appropriate for representing the survival data for all the microorganisms. Higher coefficients of determination $\left(\mathrm{R}^{2}\right)$ values were obtained (0.9975-0.9993) using the Weibull model compared to those obtained using the log-linear model (0.8946-0.9832). Furthermore, lower RMSE values were obtained using the Weibull model compared to the log-linear model in all cases, suggesting that the data fitted the Weibull model better. This was also confirmed by values of FB and NMSE being 0.0 for Weibull model (depicting a perfect fit), while higher values were obtained using the Log-linear model. Moreover, with respect to bacterial population reduction and the pattern of survival curves, no significant differences $(p>0.05$ ) were observed among the four tested waterborne pathogens in municipal water. This could be attributed to the fact that they are all Gram-negative bacteria and therefore could display a common response to the disinfectant.

\subsubsection{Modelling ozone disinfection of SWW spiked with $106 \mathrm{CFU} / \mathrm{mL}$ bacteria}

The disinfection data presented in Table 2 were modelled using the Weibull and log-linear models as shown in Fig. 4(a)-(d) and Fig. S3(a)-(d). Large discrepancies were observed between the classical first-order approach and the Weibull model in terms of the goodness-of-fit of the experimental data. The Weibull model fitted the data well which implies that it can be valuable in modelling ozone inactivation of high concentrations of microbes more realistically.

The model fitting parameters are summarised in Table S4. It is observed that the $R^{2}$ values for the Weibull model were high $(>0.96)$ while those of the log-linear model were comparatively
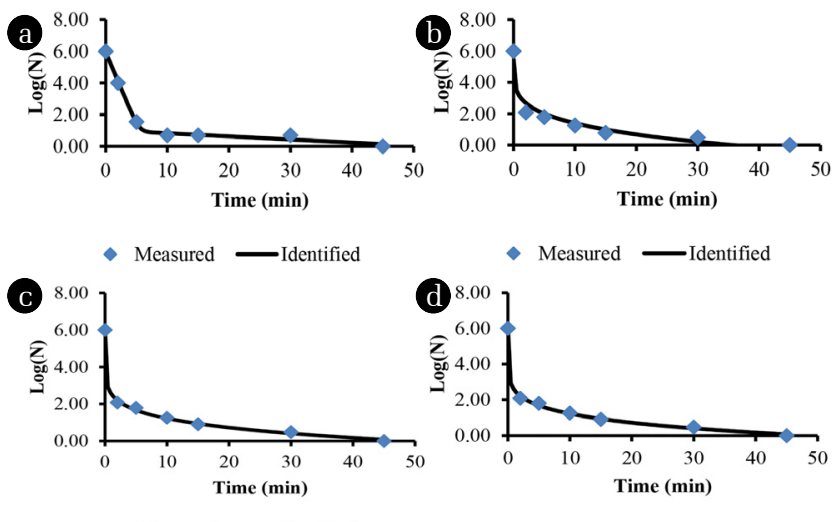

- Measured Identified

- Measured - Identified

Fig. 4. Experimental survival curve values (measured) and model fitted values (identified) derived from Weibull model for bacterial pathogens in $10^{6} \mathrm{CFU} / \mathrm{mL}$ SWW. 
low $(<0.5)$. Similarly, the RMSE values were much lower for the Weibull model (0.1-0.2) compared to those of the log-linear model (1.5-1.7). Similarly, values of 0.0 were obtained for FB and NMSE for Weibull model, while much higher corresponding values were obtained using the Log-linear model. The implication of this is that the use of the first-order kinetics to describe ozone disinfection does not present a realistic inactivation profile especially at high bacterial concentrations. The higher the accuracy of model fitting, the more reliable the prediction of the microbial inactivation [33].

\subsection{Evaluation of the Inactivation Models}

The log-linear model (Eq. (5)) has traditionally been used to describe microbial inactivation. However, ozone disinfection systems do not generally display first-order kinetics [10]. Typical log-log survival plots exhibit "shoulders" (concave downward) or "tailing" (concave upward) which necessitates the use of a model that includes the shape parameter $(\beta)$. The Weibull distribution displays upward concavity in the survival curve if $\beta<1$ and downward concavity if $\beta>1$; moreover, the Weibull model obeys first-order kinetics for $\beta=1$. The importance of the Weibull model is that although it is of an empirical nature, links with physiological effects can be made. For instance, in the present study, the survival curves were concave downward $(\beta>1)$, thereby indicating that the microbial cells were weakened and became increasingly susceptible to damage during ozone treatment [32, 34]. It was further observed that the inactivation seemed to occur in two stages: an initial rapid stage and a final slow stage exhibiting a tailing mechanism especially for high bacterial concentrations. This decreasing inactivation during the second stage is probably as a result of the self-defence mechanisms adopted by the bacteria in order to limit oxidative stress [35] or as a result of an inhibition phenomenon produced by the competition for the disinfectant by the organic products released to the medium during cell lysis [36]. Overall, the RMSE, FB, NMSE and $R^{2}$ values obtained for the Weibull model were better than those obtained for the log-linear model. These results corroborate the findings of Bialka and colleagues [37] who reported that the Weibull model described the ozone disinfection kinetics better than the first order kinetics.

\subsection{Evaluation of Bacterial Re-growth}

To determine whether complete disinfection of SW and SWW had been achieved, bacterial re-growth studies were conducted on the samples after $24 \mathrm{~h}$ and the results are shown in Fig. 5. It was observed that there was bacterial re-growth in the SW as well as the SWW samples for all the bacterial species despite complete inactivation having been achieved (Fig. 1 and 2). The bacterial reactivation ( $D$ value) was lower in SW (1 to 3.9\%), compared to SWW (0 to 5\%), notwithstanding the initial bacterial concentrations of the two water types. Nevertheless, the increase in the number of culturable bacteria during the $24 \mathrm{~h}$ post-ozonation phase could be attributed to the nutrition provided by the organic matter in the wastewater as well as new sources of nutrition arising from the oxidation of the biomass in the wastewater [38]. These nutrients could provide a food source for the injured bacteria thereby enabling them to metabolise and reproduce. Furthermore, in some instances, the temporarily inactivated bacteria may enter a viable but non-cul- turable stage and then recover their culturability after a period of more favourable conditions during storage of treated wastewater [25]. Moreover, these results show that re-growth of the microorganisms cannot be prevented during ozonation because of the difficulty in maintaining residual ozone. This is attributed to the fact that ozone is a highly unstable molecule with a very short half-life in water (shorter than in air) and relatively low solubility in water [16]. Therefore, it has been recommended that ozone be used as a primary disinfectant and a secondary disinfectant such as chlorine must then be used to maintain a residual protection [16]. This will substantially reduce the amount of chlorine required and therefore minimise the formation of chlorination disinfection by-products. Furthermore, the use of a stronger oxidant such as ozone as a primary disinfectant will effectively damage the cell wall surfaces and therefore enhance the facile penetration of subsequently applied free chlorine.
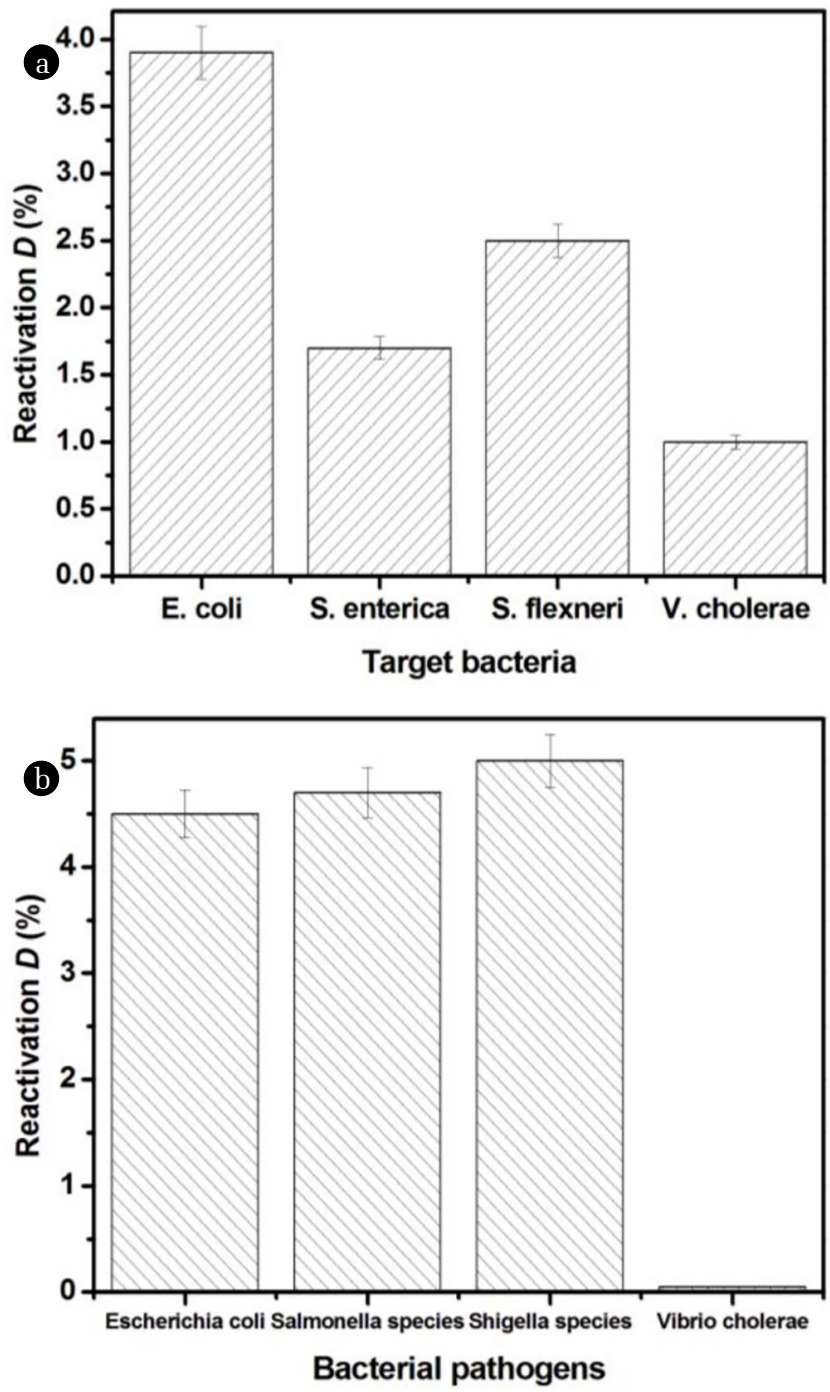

Fig. 5. (a) Reactivation values after ozonation of SW and storage in the dark (1,440 min); (b) Reactivation values after ozonation of SWW and storage in the dark (1,440 min). 
The study has shown the efficacy of ozone in the disinfection of wastewater containing different microbial concentrations. Ozone disinfection is effective even at high bacterial concentrations which are higher than those employed in recent studies [16] or present in typical secondary municipal wastewater. In terms of application, considering that disinfection is the final unit process in wastewater treatment, ozone can be retrofitted without interfering with the plant or treatment process. For instance, where chlorine is currently used for disinfection, the chlorine contactor can be readily modified to accommodate ozone dosing.

\section{Conclusions}

The study evaluated the ozone disinfection kinetics of synthetic and actual wastewater samples containing Escherichia coli and waterborne pathogens (Salmonella species, Shigella species, and Vibrio cholerae). At high bacterial concentrations $\left(10^{6} \mathrm{CFU} / \mathrm{mL}\right)$, the Weibull model gave a better fit to the disinfection data than the commonly used log-linear model for all the microorganisms investigated. The water matrix was found to be an important factor and the results showed that there was minimal bacterial re-growth in the SW compared to the SWW samples (irrespective of lower initial bacterial concentrations in SWW). This confirms the need to conduct disinfection studies using real wastewater in order to obtain realistic results on disinfectant performance since it is not possible to extrapolate the survival data of pure-cultures to bacterial response in real natural wastewater. Moreover, no significant differences $(p>0.05)$ were observed among the four tested bacterial species with respect to the reduction in bacterial populations and the pattern of survival curves. For practical application, since ozone decomposes rapidly in water, ozone can be used as a primary disinfectant and a secondary disinfectant such as chlorine must then be used in order to provide residual protection. This is envisaged to reduce the required dose of the secondary disinfectants, thus minimising the formation of disinfection by-products.

\section{Acknowledgment}

The National Research Foundation and the Africa Centre of Excellence II in Phytochemicals, Textile and Renewable Energy, Moi University are acknowledged.

\section{Author Contributions}

A.C.M. (Dr) conducted all the experiments and writing of the manuscript. M.S.O. (Professor) participated in writing the manuscript. A.O. (Professor) participated in writing the manuscript. M.NB.M. (Professor) participated in writing the manuscript.

\section{References}

1. Silva GHR, Daniel LA, Bruning H, Rulkens WH. Anaerobic effluent disinfection using ozone: Byproducts formation. Bioresour. Technol. 2010;101:6981-6986.

2. Gray NF. Ozone Disinfection. In: Percival SL, Yates MV, Williams DW, Chalmers RM, Gray NF, eds. Microbiology of Waterborne Diseases, $2^{\text {nd }}$ ed. London: Academic Press; 2014. p. 599-615.

3. Zuma F, Lin J, Jonnalagadda SB. Ozone initiated disinfection kinetics of Escherichia coli in water. J. Environ. Sci. Health., Part A. 2009;44:48-56.

4. Long BW, Hulsey RA, Hoehn RC. Complementary uses of chlorine dioxide and ozone for drinking water treatment. Ozone Sci. Eng. 1999;21:465-76.

5. Mišík M, Knasmueller S, Ferk F, et al. Impact of ozonation on the genotoxic activity of tertiary treated municipal wastewater. Water Res. 2011;45:3681-3691.

6. Muñoz I, Rodríguez A, Rosal R, Fernández-Alba AR. Life Cycle Assessment of urban wastewater reuse with ozonation as tertiary treatment: A focus on toxicity-related impacts. Sci. Total Environ. 2009;407:1245-1256.

7. Janex ML, Savoye P, Roustan M, Do-Quang Z, Laîné JM, Lazarova V. Wastewater Disinfection by Ozone: Influence of Water Quality and Kinetics Modeling. Ozone Sci. Eng. 2000;22: 113-121.

8. Cullen PJ, Tiwari BK, O'Donnell CP, Muthukumarappan K. Modelling approaches to ozone processing of liquid foods. Trends. Food Sci. Technol. 2009;20:125-136.

9. Hunt NK, Mariñas BJ. Kinetics of Escherichia coli inactivation with ozone. Water Res. 1997;31:1355-1362.

10. Garcia Loredo AB, Guerrero SN, Alzamora SM. Inactivation kinetics and growth dynamics during cold storage of Escherichia coli ATCC 11229, Listeria innocua ATCC 33090 and Saccharomyces cerevisiae KE162 in peach juice using aqueous ozone. Innov. Food Sci. Emerg. 2015;29:271-279.

11. Smeets PWMH, van der Helm AWC, Dullemont YJ, Rietveld LC, van Dijk JC, Medema GJ. Inactivation of Escherichia coli by ozone under bench-scale plug flow and full-scale hydraulic conditions. Water Res. 2006;40:3239-3248.

12. Walt M, Krüger M, Walt C. The South African oxidation and disinfection manual, TT 406/09. Water Research Commission; 2009.

13. Venieri D, Fraggedaki A, Kostadima M, et al. Solar light and metal-doped $\mathrm{TiO}_{2}$ to eliminate water-transmittedbacterial pathogens: Photocatalyst characterization and disinfectionperformance. Appl. Catal., B. 2014;154-155:93-101.

14. Li D, Zeng S, Gu AZ, He M, Shi H. Inactivation, reactivation and regrowth of indigenous bacteria in reclaimed water after chlorine disinfection of a municipal wastewater treatment plant. J. Environ. Sci. 2013;25:1319-1325.

15. Devatkal SK, Jaiswal P, Kaur A, Juneja V. Inactivation of Bacillus Cereus and Salmonella Enterica Serovar Typhimurium by Aqueous Ozone: Modeling and UV-Vis Spectroscopic Analysis. Ozone Sci. Eng. 2016;38:124-132.

16. Demir F, Atguden A. Experimental investigation on the microbial inactivation of domestic well drinking water using ozone under different treatment conditions. Ozone Sci. Eng. 2016;38: 25-35.

17. Mecha AC, Onyango MS, Ochieng A, Momba MN. Impact of 
ozonation in removing organic micro-pollutants in primary and secondary municipal wastewater: effect of process parameters. Water Sci. Technol. 2016;74:756-765.

18. APHA. Standard methods for the examination of water and wastewater. $21^{\text {st }}$ ed. American Public Health Association/ American Water Works Association/Water Environment Federation, Washington DC; 2005.

19. Chick H. An investigation of the laws of disinfection. J. Hyg. 1908;8: 92-158.

20. Watson HE. A note on the variation of rate of disinfection with the change in the concentration of disinfectant. J. Hyg. 1908;8:536-542.

21. Mafart P, Couvert O, Gaillard S, Leguerinel I. On calculating sterility in thermal preservation methods: Application of the Weibull frequency distribution model. Int. J. Food Microbiol. 2002;72:107-113.

22. Geeraerd AH, Valdramidis VP, Van Impe JF. GInaFiT, a freeware tool to assess non-log-linear microbial survivor curves. Int. J. Food Microbiol. 2005;102:95-105.

23. Ferrario M, Alzamora SM, Guerrero S. Inactivation kinetics of some microorganisms in apple, melon, orange and strawberry juices by high intensity light pulses. J. Food Eng. 2013;118: 302-11.

24. Chang JC, Hanna SR. Air quality model performance evaluation. Meteorol. Atmos. Phys. 2004;87:167-96.

25. McCullagh C, Robertson JMC, Bahnemann DW, Robertson PKJ. The application of $\mathrm{TiO}_{2}$ photocatalysis for disinfection of water contaminated with pathogenic micro-organisms: a review. Res. Chem. Intermed. 2007;33:359-375.

26. Langlais B, Reckhow DA, Brink DR. Ozone in water treatment: Application and engineering. USA: Lewis Publishers, Inc; 1991. p. 569.

27. Xu P, Janex M-L, Savoye P, Cockx A, Lazarova V. Wastewater disinfection by ozone: Main parameters for process design. Water Res. 2002;36:1043-1055.

28. Michael-Kordatou I, Andreou R, Iacovou M, et al. On the capacity of ozonation to remove antimicrobial compounds, resistant bacteria and toxicity from urban wastewater effluents. J. Hazard. Mater. 2017;322:414-425.

29. Sousa JM, Macedo G, Pedrosa M, et al. Ozonation and UV254 $\mathrm{nm}$ radiation for the removal of microorganisms and antibiotic resistance genes from urban wastewater. J. Hazard. Mater. 2017;323, Part A:434-441.

30. Paraskeva P, Lambert SD, Graham NJD. Influence of Ozonation Conditions on the Treatability of Secondary Effluents. Ozone Sci. Eng. 1998;20:133-150.

31. Liberti L, Notarnicola M, Lopez A. Advanced treatment for municipal wastewater reuse In Agriculture. III - Ozone Disinfection. Ozone Sci. Eng. 2000;22:151-166.

32. Van Boekel MAJS. On the use of the Weibull model to describe thermal inactivation of microbial vegetative cells. Int. J. Food Microbiol. 2002;74:139-159.

33. Albert I, Mafart P. A modified Weibull model for bacterial inactivation. Int. J. Food Microbiol. 2005;100:197-211.

34. Kacem M, Bru-Adan V, Goetz V, et al. Inactivation of Escherichia coli by $\mathrm{TiO}_{2}$-mediated photocatalysis evaluated by a culture method and viability-qPCR. J. Photochem. Photobiol., A. 2016;317:81-87.

35. Rincón A-G, Pulgarin C. Use of coaxial photocatalytic reactor (CAPHORE) in the $\mathrm{TiO}_{2}$ photo-assisted treatment of mixed $E$. coli and Bacillus sp. and bacterial community present in wastewater. Catal. Today. 2005;101:331-344.

36. Marugán J, van Grieken R, Sordo C, Cruz C. Kinetics of the photocatalytic disinfection of Escherichia coli suspensions. Appl. Catal., B. 2008;82:27-36.

37. Bialka KL, Demirci A, Puri VM. Modeling the inactivation of Escherichia coli O157:H7 and Salmonella enterica on raspberries and strawberries resulting from exposure to ozone or pulsed UV-light. J. Food Eng. 2008;85:444-449.

38. Wist J, Sanabria J, Dierolf C, Torres W, Pulgarin C. Evaluation of photocatalytic disinfection of crude water for drinking-water production. J. Photochem. Photobiol., A. 2002;147:241-246. 